E-JURNAL EKONOMI DAN BISNIS UNIVERSITAS UDAYANA
Available online at https://ojs.unud.ac.id/index.php/EEB/index
Vol. 10 No. 01, January 2021, pages: 45-52
e-ISSN: 2337-3067

\title{
PENGARUH LOVE OF MONEY DAN PERILAKU MACHIAVELLIAN TERHADAP PERSEPSI ETIS INTERNAL AUDITOR BANK PERKREDITAN RAKYAT
}

\author{
Putu Aristya Adi Wasita ${ }^{1}$, Ni Nengah Lasmini²
}

Article history:

Submitted: 17 Desember 2020

Revised: 5 Januari 2021

Accepted: 11 Januari 2021

\section{Keywords:}

love of money;

Machiavellian;

Internal auditors ethical perception;

\section{Kata Kunci:}

Kecintaan terhadap uang;

Perilaku Machiavellian;

Persepsi Etis Internal Auditor;

\section{Koresponding:}

Fakultas Ekonomi Bisnis dan Humaniora Program Studi Akuntansi, Universitas Dhyana Pura, Badung, Bali, Indonesia Email:

ariswasita@undhirabali.ac.id
Abstract

Assessment of conditions or mistakes is called ethical perception. A person who works as an accountant will make high reservations by sticking to existing ethical standards. Competition is tighter, so the accounting profession must often clash with efforts to stick to ethical standards. The internal auditor's view in assessing an improper act will provide a perception of ethical perceptions for the community related to accountability and transparency. This research was conducted to get the influence of the variable love of money, Machiavellian with gender as a moderator on the ethical perceptions of the people's prekreditan bank internal auditors. The data in the study were collected using a questionnaire method, so that the research data were classified as primary data. This study will use 43 samples and will be analyzed using moderated regression analysis. The results of the study, after going through the data analysis of love of money and Machiavellian, have a negatif effect on the ethical perception variable of BPR internal auditors. Gender as a moderating variable assesses the influence the love of money variable on the ethical perceptions of BPR internal auditors while for Machiavellian, gender does not know

Abstrak
Seorang yang berprofesi sebagai akuntan akan mengalami suatu
tuntutan yang tinggi dengan tetap berpatokan pada standar etika yang telah
ada. Pada era sekarang profesi akuntan harus sering kali akan
bersinggungan dengan usaha untuk tetap pada standar kode etis. Pandangan
internal auditor dalam menilai suatu tindakan yang tidak benar akan dapat
memberikan suatu cerminan persepsi etis bagi masyarakat terkait dengan
akuntabilitas dan transparasi. Dilakukannya penelitian ini untuk
mendapatkan pengaruh dari variabel love of money, Machiavellian dengan
gender sebagai pemoderasi terhadap persepsi etis internal auditor bank
prekreditan rakyat. Data dalam penelitian ini dikumpulkan menggunakan
metode kuesioner, sehingga data penelitian tergolong data primer.
Penelitian ini akan menggunakan 43 sampel, karena jumlah sampel
tergolong kecil maka teknik sampel jenuh yang akan digunakan. Data yang
telah didapatkan akan dianalisis dengan moderated regression aanalysis.
Hasil penelitian setelah melalui analisis data menyatakan love of money dan
variabel bebas lainya perilaku Machiavellian memiliki pengaruh negatif
terhadap variabel persepsi etis internal auditor BPR. Gender sebagai
variablel pemoderasi memperkuat pengaruh dari variabel love of money
terhadap variabel persepsi etis internal auditor BPR sedangkan untuk
Machiavellian, gender tidak memperkuat.
Machiavellian, gender tidak memperkuat.

Fakultas Ekonomi Bisnis dan Humaniora Program Studi Akuntansi, Universitas Dhyana Pura, Badung, Bali, Indonesia ${ }^{2}$

Email: nengahlasmini@undhirabali.ac.id 


\section{PENDAHULUAN}

Permasalahan akuntansi yang muncul khusunya di perbankan disebabkan karena etika professional seorang akuntan terlebih khusus dalam hal ini adalah internal auditor. Sukrisno \& Ardana (2017) mengemukakan pendapatnya mengenai bahwa suatu kejadian dan tindakan benar dan salah berhubungan dengan etika. Hal lain tidak terlepas adalah profesi seorang internal auditor erat kaitannya dengan uang. Sebagian alasan yang mempengaruhi pada keputusan ataupun perilaku tidak benar dalam suatu organisasi bagi Jan Hoesada (2012) adalah merupakan keinginan pribadi, tidak terdapatnya prinsip dalam diri orang, sikap dan perilaku yang dijalakan setiap harinya oleh orang tersebut, lingkungan tidak benar, memilih keputusan yang tidak baik.

Manusia di dalam kehidupannya membutuhkan uang, dimana hal tersebut merupakan hal yang sangat penting. Tang (1992) mengemukakan konsep teoritis tentang cinta uang sebagai pedoman psikologis yang mengukur perasaan subjektif seseorang. Alibi dari konsep ini tidak lain merupakan berartinya kegunaan uang serta perbandingan pemikiran masyarakat tentang uang. Cinta uang mengukur besarnya kecintaan seorang terhadap uang yang nantinya hendak mempengaruhi anggapan etikanya. Tang (1988) mengemukakan teori pengukuran ialah Money Ethic Scale (MES) yang bertujuan buat mengukur perasaan subjektif seorang terhadap uang. Kecintaan tiap orang pada uang berbeda-beda bergantung kebutuhan yang dimilikinya serta dipengaruhi oleh sebagian hal lain, antara lain aspek demografis seperti gender, umur, tingkatan pembelajaran, status sosial ekonomi, serta etnis. Riset sebelumnya yang memiliki kesamaan variabel love of money memperlihatkan love of money berkaitan pada sebagian sikap organisasi yang diidamkan serta tidak diidamkan.

Perilaku machiavellian yang bisa menimbulkan seorang berperilaku tidak etis. Richmond (2003) menciptakan teori kalau karakter orang pengaruhi sikap etis. Richmond menyelidiki ikatan antara machiavellianisme yang membentuk jenis karakter yang membentuk watak machiavellian dalam melakukan suatu pertimbangan etis pada saat terjadi dilema etis. Riset yang telah dilakukan Richmond ini memperlihatkan jika semakin tinggi kecenderungan Machiavellian seorang, kemungkinan besar ia bertindak tidak etis. Kedua, jika menjadi tinggi tingkatan pertimbangan etis seorang, maka orang tersebut akan kemungkinan besar berperilaku etis. Selain itu gender juga menjadi faktor yang menentukan dalam sikap berprilaku etis, Bersumber pada Coate \& Frey (2000), terdapat 2 pendekatan yang universal digunakan buat membagikan opini tentang pengaruh gender terhadap sikap etis serta anggapan orang terhadap sikap tidak etis, ialah dua pendekatan. Pendekatan struktural memberikan perbandingan laki-laki dan perempuan dikarenakan pergaulan di tempat kerja.

Sedangkan pendekatan sosialisasi lebih menekankan jika laki-laki dan perempuan membawa suatu nilai ke tempat kerjanya. Perbandingan nilai serta ciri bersumber pada gender ini menjadi dasar laki-laki dan perempuan dalam pengambilan pilihan serta penerapannya. Salah satu profesi yang terkait dengan persepsi etis adalah internal auditor bank perkreditan rakyat yang selanjutnya disingkat dengan BPR. Audit internal di area BPR menggambarkan bagian dari peranan pengawasan ataupun pengaturan dalam (internal kontrol), begitu juga diatur dalam POJK no 4 mengenai aturan tata kelola, yang setelah itu diturunkan dalam wujud Surat Edaran no 7. Internal auditor akan dihadapkan pada konflik kepentingan pribadi dan tujuan perusahaan. Sehingga persepsi etis dari seorang internal auditor perlu untuk diketahui pada saat menjalankan peran dan tugasnya.

Tang \& Chiu (2003), Elias(2010) serta penelitian yang telah dilakukan oleh Charismawati (2011), Dzakirin (2013), Normadewi (2012) dan (Teragung, 2015) sudah mempelajari faktor-faktor yang pengaruhi tindakan, sikap serta anggapan etis seorang. Basri (2015) dan Sugiantari (2016) melaksanakan riset memakai sebagian persepsi etis ataupun aspek yang pengaruhi anggapan etis, antara lain kecintaan pada uang, machiavellian serta jenis kelamin.

Banyak hasil riset yang sudah ada mengenai sikap etis. Tetapi, tipe aspek yang dipelajari berlainan satu dengan yang lain. Tidak hanya itu, ditemukan terdapatnya inkonsistensi hasil riset antara satu riset dengan riset yang lain dikarenakan terdiri dari banyak aspek. Ketidakkonsistenan hasil riset dari penelitian-penelitian sebelumnya membuktikan bahwa riset ini butuh dikaji kembali. Riset ini

Pengaruh Love of Money dan Perilaku Marchiavelian Terhadap Persepsi Etis Internal 
hendak menguji kembali faktor- faktor yang mempunyai keinkonsistenan. Dalam riset ini faktor- faktor yang ditelitii merupakan sikap machiavellian, perilaku etika serta gender pada internal auditor BPR.

Teori harapan pada mulanya dikemukakan pada tahun 1964 oleh Victor Vroom. Victor Vroom (1990) melaporkan bahwa seorang hendak termotivasi melaksanakan keadaan khusus untukt mencapai tujuan. Mereka percaya jika perbuatan yang mereka lakukan bertujuan mencapai sesuatu hal yang diinginkan. faktor kunci dalam teori ini adalah suatu upaya, hasil, harapan, instrumen yang berhubungan dengan ikatan antara hasil tingkatan awal serta tingkatan kedua yang berhubungan dengan kadar daya serta kemauan seorang kepada hasil khusus (Lubis, 2014). Dimana hasil tingkatan awal berarti pemikiran ataupun sikap yang muncul

Persepsi berdasarkan yang disampaikan Gibson (1969) dalam Normadewi (2012) persepsi menggambarkan metode untuk menguasai lingkungannya mencakup subjek, orang, dan tanda ataupun ciri yang mengaitkan cara kognitif (identifikasi). Proses kognitif sendiri menggambarkan metode dimana orang membagikan maksud melalui penafsirannya kepada rangsangan (dorongan) yang timbul dari subjek, orang, serta tanda khusus. Oleh sebab itu, anggapan melingkupi pendapatan, pengorganisasian, serta pengertian dorongan yang sudah diorganisasi dengan metode yang bisa pengaruhi sikap serta membuat tindakan. Perihal tersebut terjalin karena anggapan mengaitkan pengertian orang pada subjek khusus, akibatnya tiap-tiap subjek hendak mempunyai anggapan yang berbeda meski memandang subjek yang serupa.

Pendapat yang dikemukan oleh Richmond (2001) filosofi perkembangan moral kognitif memperkirakan orang dengan estimasi bermoral rendah tidak mampumengerjakan pertimbangan etis yang lebih besar. Dimana ada 3 aspek yang memisahkan pertimbangan etis dengan seluruh cara psikologis yang lain. Faktor-faktor itu merupakan: (1) kesadaran bersumber pada pada nilai serta bukan pada kenyataan yang tidak jelas, (2) evaluasi didasarkan atas sebagian rumor yang mengaitkan diri sendiri serta orang lain, serta (3) penilaian didasarkan atas sebagian rumor dari sumber atas beberapa pilihan.

Teori love of money menggambarkan karakter dari individu yang memiliki kecintaan terhadap uang. Kecintaan seorang terhadap uang terutama pada karyawan bisa mempengaruhi kinerjanya serta hal ini akan pengaruhi kemampuan dari Lembaga dimana orang tersebut bekerja. Bagi Choe et. al (2011) ada empa aspek kecintaan kepada uang adalah aspek kekayaan, motivator, berhasil serta arti bernilai. Machiavellianism dijelaskan sebagai suatu cara dimana manipulator memperoleh balasan lebih pada saat mereka melakukan tindakan kecurangan, sedangkan orang lain memperoleh kurang tanpa melaksanakan kecurangan, paling tidak dalam kondisi langsung (Richmod 2001).

Pada teori harapan diuraikan seorang akan termotivasi untuk melaksanakan hal- hal tertentu untuk meraih tujuan jika mereka percaya bahwa tindakan mereka hendak berorientasi pada pencapaian tujuan itu walaupun dengan melaksanakan berbagai cara. Penelitian yang dihasilkan oleh Tang \& Chiu (2003) dan penelitian Sugiantari \& Widanaputra (2016) bahwa semakin besar love of money hingga akan semarin kecil persepsi etis. Berlandaskan uraian diatas, sehingga hipotesis yang diajukan dalam riset ini yaitu: H1: love of money berpengaruh negatif terhadap persepsi etis internal auditor BPR

Sikap machiavellian yang menggambarkan sesuatu pemikiran ataupun anggapan sehubungan dengan ikatan antar perorangan, dimana hal ini bisa dimaksud sebagai hasil tingkatan awal. Kemudian anggapan itu hendak membentuk karakter yang melandasi tindakan dalam berkorelasi tiap orang serta bisa merupakan hasil tingkatan kedua. Keterkaitan antar perorangan, tiap orang yang mempunyai tingkatan machiavellian tinggi akan kurang memiliki afeksi pada hubungan perorangan, melalaikan etiket serta mengarah manipulatif Hasil riset Novitasari \&Sukirno (2016) dan Teragung \&Halaman (2015) membuktikan bila machiavellian mempengaruhi negatif kepada persepsi etis. Hal ini berarti seorang yang mempunyai perilaku machiavellian yang menjurus tinggi akan berdampak memiliki persepsi etis yang kecil begitu juga sebaliknya. H2: machiavellian berpengaruh negatif terhadap persepsi etis internal auditor BPR

Pada teori harapan yang dikemukan oleh Victor Vroom. Victor Vroom (1990) menyatakan bahwa seorang hendak termotivasi melaksanakan keadaan khusus untukt mencapai tujuan. Laki-laki mengarah lebih berkeinginan meraih yang dicita-citakan, akibatnya laki-laki berkeinginan dan

Pengaruh Love of Money dan Perilaku Marchiavelian Terhadap Persepsi Etis Internal 
termotivasi untuk melaksanakan halhal khusus untuk meraih tujuan mereka. Laki- laki mempunyai keinginan pada kedudukan, gelar serta kewenangan yang menimbulkan mereka lebih mencintai uang dibandingkan perempuan. Laki-laki mengutamakan uang, kesuksesan serta kewenangan dibandingkan dengan nilai akibatnya laki-laki mengarah melalaikan moral untuk memperoleh apa yang mereka impikan dimana salah satunya merupakan uang dibanding dengan perempuan (Sugiharti,2016). Sehingga bisa dikatakan bila laki- laki lebih mempunyai kecintaan pada uang ataupun love of money lebih besar dibandingkan perempuan. Berlandaskan uraian diatas, sehingga hipotesis yang diajukan dalam riset ini yaitu: H3: Gender memperkuat pengaruh lofe of money terhadap persepsi etis internal auditor BPR

Teori moral kognitif (Sari, 2016) membuktikan terdapatnya ikatan kokoh antara pertimbangan moral serta gender, dimana perempuan mempunyai pertimbangan moral lebih besar dibandingkan dengan laki- laki. Laki- laki lebih mengarah melaksanakan sikap tidak benar karena lebih fokus pada keberhasilan dengan cara bersaing alhasil mengarah melalaikan ketentuan untuk menggapai keberhasilan, kebalikannya wanita lebih jelas dalam bersikap benar sehingga mengarah tidak ingin melaksanakan pekerjaan yang merugikan ataupun mencelakakan orang lain seperti melanggar ketentuan ataupun bersikap tidak jujur serta manipulatif serta lebih memutuskan patuh pada peraturan. Laki-laki mempunyai watak machiavellian lebih besar dibandingkan perempuan, serta membuktikan bila laki-laki serta perempuan mempunyai persepsi etis yang tidak serupa (Widyawati dan Sukhemi, 2016). Berlandaskan uraian diatas, sehingga hipotesis yang diajukan dalam riset ini yaitu: H4: Gender memperkuat pengaruh machiavellian terhadap persepsi etis internal auditor BPR

\section{METODE PENELITIAN}

Riset ini dilakukan pada dalam auditor dari BPR. Jumlah sampel yang didapat sebesar 43 sampel dengan metode sampel jenuh. Bersumber pada sumbernya, data yang dipakai dalam riset ini merupakan data primer. Data primer dalam riset ini dikunpulkan melalui teknik angket. Instrumen riset ini dibentuk dari variabel-variabel riset dengan sejumlah item khusus yang diformulasikan bersumber pada indikator tiap variabel yang diadaptasi serta dipakai sebagai referensi. Angket yang diisi oleh responden dibuat dalam struktur pertanyaan tertutup, dimana dalam angket tersebut telah didetetapkan disediakani pilihan jawaban dari masing-masing pertanyaan yang diberikan. Dalam penerapan pengisian nantinya responden hanya memilah salah satu jawaban yang sesuai dengan keadan yang dirasakan responden. Angket telah disebarkan ke 25 BPR yang berada di Kecamatan Mengwi, Kabupaten Badung, Bali. Responden yang telah mengisi angket dalam riset ini merupakan 43 orang internal auditor BPR. Teknik analisis data adalah pengolahan serangkaian data dan informasi. Tujuan dari analisis data adalah mempermudah informasi dalam wujud yang lebih dapat dibaca serta diinterpretasi. Dalam riset ini data dan informasi dianalisis dengan Moderated Regression Analysis (MRA).

\section{HASIL DAN PEMBAHASAN}

Determinasi ilustrasi yang dipakai dalam riset ini merupakan Metode sampel jenuh. Sehingga jumlah ilustrasi dalam riset ini merupakan 43 responden. Berikut ini merupakan hasil Tabel 1 statistik deskriptif. Bersumber pada hasil tabel 1 diketahui bahwa love of money mempunyai nilai 116,9 untuk rata-rata, nilai 16,9 untuk standar deviasi. Selain itu diperoleh nilai minimal dan maksimalnya yaitu 55 dan 134. Sedangkan machiavellian dengan nilai 77,4 untuk rata-rata dengan standar deviasi 10,8. Nilai minimal dari machiavellian 40 serta nilai maksimal 96. Persepsi etis internal auditor mempunyai nillai 17,9 yang merupakan nilai rata-ratanya sednilain standar deviasi 3,7. Nilai minimal 12 serta maksimal 32. Ketiga variabel diatas memiliki nilai standar devisiasi lebih kecil dibandingkan nilai rata- rata membuktikan ketiga variabel tersebut berlainan jauh antara satu responden dengan responden yang yang lain.

Pengaruh Love of Money dan Perilaku Marchiavelian Terhadap Persepsi Etis Internal Auditor Bank Perkreditan Rakyat Putu Aristya Adi Wasita dan Ni Nengah Lasmini 
Uji ini dilakukan untuk mengukur apakah variabel residual dalam bentuk regresi mempunyai penyebaran wajar. Tabel 2 membuktikan informasi berdistribusi wajar, dengan nilai signifikansinya sebesar 0,124 . Hal ini berarti $0,124>0,05$.

Tabel 1.

Uji Analisis Deskriptif

\begin{tabular}{lccccc}
\hline & N & Minimum & Maximum & Mean & Std.Deviation \\
& & & & & \\
\hline Love of money & 43 & 55 & 134 & 116,9 & 16,9 \\
Machiavellian & 43 & 40 & 96 & 77,4 & 10,8 \\
$\begin{array}{l}\text { Persepsi Etis } \\
\text { Internal Auditor }\end{array}$ & 43 & 12 & 32 & 17,9 & 3,7 \\
Valid N & 43 & & & & \\
\hline
\end{tabular}

Sumber: Data Diolah (2020)

Tabel 2.

Uji Normalitas

\begin{tabular}{ll}
\hline & Unstandardized Residual \\
\hline $\mathrm{N}$ & 43 \\
Nilai Kolmogorov SZ & 1,180 \\
Signifikansi & 0,124 \\
\hline
\end{tabular}

Sumber: data diolah (2020)

Percobaan multikolonieritas untuk mengukur terdapat tidaknya hubungan dari semua variabel bebas. Pada tabel dibawah ini membuktikan nilai dari VIF untuk tiap variabel bebas nilainya lebih kecil dari 10 dan nilai tolerance lebih besar dari 0,1, dapat disimpulkan bebas multikolinieritas.

Tabel 3

Uji Multikolinearitas

\begin{tabular}{lll}
\hline Variabel & Tolerance & VIF \\
\hline Love of money & 0,212 & 4,719 \\
Machiavellian & 0,476 & 2,102 \\
Gender* Machiavellian $^{*}$ Lender ${ }^{*}$ Love of money & 0,173 & 5,768 \\
Gen & 0,232 & 4,314 \\
\hline
\end{tabular}

Sumber: data diolah (2020)

Percobaan autokorelasi dilakukan bermaksud untuk mencoba apakah dalamamodel regresi ada hubungan antara kekeliruan rentang waktu t dengan kekeliruan rentang waktu t- 1 . Analisa DurbinWatson didapat sebesar 1,929 dengan tingkat keyakinan 0,95. Sebaliknya bersumber pada Tabel Durbin-Watson pada jumlah sampel adalah 43 jumlah variabel adalah 3 . Sehingga $d L=1,3663$ serta nilai $\mathrm{dU}=1,6632$, nilai 4- $\mathrm{dU}=2,3368$. Nilai $\mathrm{dw} 1,929$ terdapat pada wilayah bebas autokorelasi. 
Tabel 4

Uji Autokorelasi

\begin{tabular}{ll}
\hline Nilai dw & Nilai du \\
\hline 1,929 & 1,6632 \\
\hline
\end{tabular}

Sumber: data diolah (2020)

Uji ini merupakan salah satu dari uji asumsi klasik yang dilakukan untuk mengukur terdapat ketidaksesuaian varians dari residual beberapa observasi yang dilakukan dalam sesuatu bentuk regresi. Pada Tabel 5 membuktikan tidak adanya pelanggaran heteroskedastisitas, ditunjukkan pada nilai signifikansi lebih besar dari alpha 0,05 .

Tabel 5

Uji Heteroskedastisitas

\begin{tabular}{clc}
\hline Variabel & & Sig. \\
& & \\
\hline \multirow{3}{*}{ Persamaan Regresi } & Love of money & 0,753 \\
& Machiavellian & 0,498 \\
& Gender* Machiavellian & 0,213 \\
& Gender* Love of money & 0,621 \\
\hline
\end{tabular}

Sumber: data diolah (2020)

Hipotesis di dalam riset ini diuji dengan Moderated Regression Analysis. MRA adalah aplikasi khusus regresi linear berganda dimana dalam pertemuan regresinya memiliki faktor interaksi.

Dari tabel 6, diperoleh persamaan regresi sebagai berikut :

$\mathrm{Y}=9,771-0,204 \mathrm{X}_{1}-0,310 \mathrm{X}_{2}+0,135 \mathrm{X}_{1} * \mathrm{Z}+0,164 \mathrm{X}_{2} * \mathrm{Z}+\mathrm{e}$

Persamaan diatas dapat dijelaskan sebagai berikut, konstanta dengan nilai 9,771 membuktikan bila semua variabel bebas dianggap konsisten (0), hingga nilai rata-rata persepsi etis merupakan sebesar 9,771. Love of money mempunyai koefisien $-0,204$ membuktikan pada tiap peningkatan love of money $100 \%$ akan menurunkan nilai dari persepsi etis $20,4 \%$. Machiavellian mempunyai koefisien $-0,31$ membuktikan pada tiap peningkatan Machiavellian $100 \%$ akan berakibat turunya persepsi etis $31 \%$. Interaksi variabel gender dengan love of money mempunyai koefisien 0,135 yang membuktikan gender menguatkan hubungan love of money kepada persepsi etis 13,5\%. Interaksi variabel gender dengan machiavellian mempunyai koefisien 0,164 yang membuktikan gender menguatkan hubungan machiavellian kepada persepsi etis $16,4 \%$.

Bersumber pada hasil analisa uji $\mathrm{t}$ dapat diketahui bahwa nilai $\mathrm{t}$ tabel dengan tingkatan signifikansi $\alpha=0,05$ nilai df: 43-5= 38 merupakan 2,024. Setelah dilakukan uji di tabel di atas bisa dilakukan ulasan hipotesis yang sebagai berikut, berdasarkan data pada tabel uji interaksi kalau nilai $\mathrm{t}$ hitung sebesar -5,482 probabilitas 0,000. dan t tabel 2,024 sehingga -5,482 > 2,024). Love of money secara parsial berpengaruh negatif signifikan terhadap persepsi etis internal auditor BPR. Hipotesis pertama $\left(\mathrm{H}_{1}\right)$ diterima yang bermakna love of money mempunyai pengaruh negatif signifikan terhadap persepsi etis internal auditor BPR. Seseorang yang mempunyai kecintaan terhadap uang, memiliki pola piker bahwa uang merupakan hal yang paling berarti serta menjadikannya sebagai tolok ukur suatu keberhasilan yang sanggup membuat seorang termotivasi dalam bersikap etis serta membuat persepsi etisnya jadi lebih kecil. Berdasarkan pada tabel uji interaksi kalau nilai t hitung sebesar -2,221 dengan probabilitas 0,029 dan t tabel 2,024. Secara parsial machiavellian mempengaruhi negatif signifikan terhadap persepsi etis internal auditor BPR. Hipotesis kedua $\left(\mathrm{H}_{2}\right)$ diterima bermakna machiavellian memiliki pengaruh negatif signifikan terhadap persepsi etis internal auditor BPR, dengan nilai machiavellian internal auditor BPR yang menjadi tinggi akan berdampak pada persepsi etis yang semakin kecil. Bersumber pada teori harapan yang mengatakan jika pemikiran ataupun anggapan

Pengaruh Love of Money dan Perilaku Marchiavelian Terhadap Persepsi Etis Internal

Auditor Bank Perkreditan Rakyat

Putu Aristya Adi Wasita dan Ni Nengah Lasmini 
sehubungan dengan ikatan antar perorangan akan membuat karakter yang melandasi tindakan dalam berkaitan dengan orang lain. Sehingga, didalam ikatan perorangan, seorang yang mempunyai tingkatan machiavellian besar hendak kurang memiliki afeksi dalam ikatan perorangan, melalaikan norma, etika serta mengarah manipulatif. Oleh sebab itu menyebabkan seorang mempunyai etika, norma dan akhlak yang kecil yang membuat persepsi etis seorang jadi lebih rendah

Berdasarkan pada tabel uji interaksi nilai t hitung sebesar 5,472 dengan probabilitas $0,000, \mathrm{t}$ tabel dimana 2,024. Gender secara parsial sanggup memoderasi pengaruh love of money terhadap persepsi etis internal auditor BPR. Hipotesis ketiga $\left(\mathrm{H}_{3}\right)$ diterima yang bermakna gender menguatkan adanya pengaruh dari love of money terhadap persepsi etis internal auditor BPR. Menurut teori harapan jika seorang hendak termotivasi untuk melaksanakan perihal-perihal khusus untuk menggapai tujuan yang mereka percayai bahwa kegiatan mereka hendak menuju pada pencapaian tujuan itu. Laki-laki mengarah lebih mempunyai tekad, hal tersebut membuat laki-laki lebih termotivasi untuk melaksanakan berbagai macam cara untuk dapat mencapai tujuan mereka. Lakil-laki mempunyai keinginan pada kedudukan, kewenangan yang menimbulkan perempuan lebih kecil kecintaannya terhadap uang. Hal tersebut menimbulkan perbandingan sudut pandang antara laki-laki dan perempuan. Laki-laki hendak memandang uang sebagai sesuatu hal yang berarti, menimbulkan diabaikannya norma dan akhlak untuk memenuhi keinginan terhadap uang.

Berdasarkan pada tabel uji interaksi nilai t hitung sebesar 1,790 dengan probabilitas 0,032. Nilai tabel 2,024. Secara parsial gender tidak sanggup memoderasi pengaruh machiavellian terhadap persepsi etis internal auditor BPR. Hipotesis keempat $\left(\mathrm{H}_{4}\right)$ ditolak yang bermakna gender memperkuat akibat machiavellian terhadap persepsi etis internal auditor BPR. Dalam pendekatan secara gender dikatakan bahwa perbandingan laki-laki serta perempuan diakibatkan oleh sosialisasi dini kepada profesi serta keinginan kedudukan yang lain. Sosialisasi dini ini dipengaruhi oleh penghargaan serta insentif yang diserahkan pada orang dalam sesuatu pekerjaan ataupun area. Sebab watak serta profesi membuat sikap melalui sistem penghargaan serta insentif, yang membuat laki-laki serta perempuan melakukan respon serta meningkatkan nilai etis serta akhlak dengan cara serupa dilingkungan yang serupa. Perilaku machiavellian menimbulkan kemauan memperoleh penghargaan lebih banyak. Selain itu laki-laki dan perempuan memiliki peluang untuk membuat tindakan serta sikap yang serupa dalam merespon kejadian yang berhubungan dengan nilai etis serta akhlak pada area serta profesi yang serupa. Hasil ini tidak cocok dengan teori moral kognitif bahwa bila ada ikatan kokoh antara estimasi moral dan akhlak serta gender, dimana perempuan mempunyai estimasi moral dan akhlak lebih besar dibandingkan dengan laki-laki.

\section{Tabel 6}

Uji Interaksi

\begin{tabular}{lccccc}
\hline & \multicolumn{1}{c}{ B } & Std Error & Beta & $\boldsymbol{t}$ & Sig. \\
\hline (Constant) & 9,771 & 2,571 & & 3,800 &, 000 \\
Love of money &,- 204 &, 037 & $-1,128$ & $-5,482$ &, 000 \\
$\begin{array}{l}\text { Machiavellian } \\
\text { Gender*Love }\end{array}$ &,- 310 &, 140 &,- 501 & $-2,221$ &, 029 \\
$\begin{array}{l}\text { money } \\
\text { Gender*Machiavellian }\end{array}$ &, 135 &, 025 & 1,360 & 5,472 &, 000 \\
\hline Adjusted Rsquare &, 164 &, 092 &, 435 & 1,790 &, 077 \\
F hitung &, 420 & & & & \\
Signifikansi F & 3,097 & & & & \\
F tabel &, 000 & & & & \\
\hline
\end{tabular}

Sumber: data diolah (2020)

Pengaruh Love of Money dan Perilaku Marchiavelian Terhadap Persepsi Etis Internal Auditor Bank Perkreditan Rakyat Putu Aristya Adi Wasita dan Ni Nengah Lasmini 


\section{SIMPULAN DAN SARAN}

Hasil riset membuktikan jika persepsi etis BPR akan dipengaruhi secara negatif dan signifikan oleh love of money serta machiavellian. Hasil tersebut memiliki makna bahwa seorang yang mempunyai tingkatan love of money dan machiavellian besar sehingga persepsi etisnya jadi lebih kecil. Sedangkan Gender mampu memoderasi pengaruh love of money terhadap persepsi etis internal auditor BPR. Tetapi pada variabel machiavellian terhadap persepsi etis internal auditor BPR, gender tidak mampu untuk memoderasinya.

Penelitian ini memiliki beberapa keterbatasan, yakni jumlah sampel yang relatif kecil dan hanya membahas beberapa variabel sebagai penelitian, saran yang dapat diberikan bagi penelitian selanjutnya, jika tetap ingin meneliti internal auditor BPR dapat menambahkan variabel dan dapat menggunakan sampel dengan jumlah lebih besar sehingga akan dapat memperoleh hasil yang lebih baik dan jelas tentang persepsi etis.

\section{REFERENSI}

Agoes, Sukrisno dan I Cenik Ardana. (2017). Etika Bisnis dan Profesi. Edisi Revisi. Jakarta: Salemba Empat. Arfan Ikhsan Lubis. (2011). Akuntansi Keperilakuan. Jakarta: Salemba Empat.

Charismawati, Celvia Dewi. (2011). Analisis Hubungan antara Love of money dengan Persepsi Etika Mahasiswa Akuntansi. Jurnal Akuntansi Universitas Diponegoro.

Choe. L.K., and Lau, T. (2011). Success, Rich, Motivator and Important: Establishing the Contributory Factors of Money Ethics towards Business Ethics. European Journal of Economics, Finance and Administrative Sciences. 37(9), 90-99.

Coate, C and Frey, K. (2000). Some Evidence on the Ethical Disposition of Accounting Students: Context and Gender Implications. Teaching Business Ethis, 4 (4), 379-404.

Dzakirin, M. K. (2013). Orientasi Idealisme, Relativisme, Tingkat Pengetahuan,dan Gender:. Jurnal Ilmiah Mahasiswa FEB Universitas Brawijaya,2(1).1-20.

Elias, Rafik Z. Dan Magdy Farag. (2010). The Relationship between Accounting Student's Love of money and Their Ethical Perception. Managerial Auditing Journal. 25(1). 260-281.

Normadewi, Berliana. (2012). Analisis Pengaruh Jenis Kelamin Dan Tingkat Pendidikan Terhadap Persepsi Etis Mahasiswa Akuntansi. Jurnal Akuntansi Universitas Diponegoro.8(2).23-45.

Novitasari, Erlintan Diyah dan Sukirno. (2016). Pengaruh Love of money dan Perilaku Machiavellian terhadap Persepsi Etis Mahasiswa Akuntansi. Jurnal Profita Edisi 3.4(3). 45-60.

Richmond, K. A. (2003). An Analysis of Ethical Behavior of US Undergraduate Accounting Student and Accountants. Symposium on Ethics Research in Accounting. American Accounting Association.

Sugiantari, Ni Kadek dan A.A.G.P. Widanaputra. (2016). Pengaruh Idealisme, Relativisme, Dan Love of money Pada Persepsi Mahasiswa Akuntansi Tentang Krisis Etika Akuntan. E-Jurnal Akuntansi Universitas Udayana 17(2). 2474-2502.

Tang, T. (1992). The Meaning of Money Revisited. Journal of Organization Behavior, 13(2). 197-202.

Tang, T. \& Chiu, R. (2003). Income, money ethics, pay satisfaction, commitment, and unethical behavior: is the love of money the root of evil for Hong Kong employees?. Journal of Business Ethics, 46(3). 13-30.

Vroom H. Victor. “1990”.Work and Motivation. New York: Wiley.

Widyawati, Feny \& Sukhemi, M. (2017). Pengaruh Sifat Machiavellian dan Perkembangan Moral Terhadap Dysfunctional Behavior. Akmenika: Jurnal Akuntansi dan Manajemen 14(2). 23-43. 